\title{
History "through the looking glass"
}

\author{
Karen L. Harris*
}

\begin{abstract}
This article deliberates on the South African Department of Basic Education's announcement in February 2018 to implement history as a compulsory school subject to the final year of secondary schooling. It outlines the process undertaken by the History Ministerial Task Team and assesses the report it issued, along with the initial reaction to its intent. It reflects on the chequered past of the position and place of history within the South African education system, re-visiting some of the postdemocracy debates that have perpetuated from the previous century and spilled over into the present. In the paradigm of Alice through the Looking Glass, it suggests that we might need to go "backward before going forward" in order to stop repeating this conundrum.
\end{abstract}

Keywords: school history; history curriculum; Department of Basic Education; compulsory subject; national education; post-apartheid education.

\section{Opsomming}

Hierdie artikel oorweeg die Suid-Afrikaanse Departement van Basiese Onderwys se aankondiging in Februarie 2018 om geskiedenis as 'n verpligte vak tot die finale jaar van sekondêre onderrig te implementeer. Dit dui die proses aan wat deur die Geskiedenis Ministeriele Taakspan onderneem is en assesseer die taakspan se verslag saam met die aanvanklike reaksie wat dit uitgelok het. Dit reflekteer op die uiteenlopende verlede van die plek en posisie van geskiedenis binne die SuidAfrikaanse onderwysstelsel en herbesoek die na-demokrasie debatte wat voortgesit is vanuit die vorige eeu en oorgevloei het na die hede. In die paradigma van Alice through the Looking Glass, suggereer dit dat dit dalk nodig is om "teruggaan voordat ons vorentoe" kan gaan sodat ons nie aanhou om hierdie strikvraag te herhaal nie.

Sleutelwoorde: skoolgeskiedenis; geskiedeniskurrikulum; Departement van Basiese Onderwys; verpligte vak; na-apartheid onderwys.

* Karen Harris is Head of the Department of Historical and Heritage Studies at the University of Pretoria and is also the Director of the University Archives. This article is based on the keynote address at the HASA biennial conference, 21 June 2018. Her email address is: karen.harris@up.ac.za 


\section{Looking at the Looking Glass}

The alliterated theme, "Miracles and Mirages",1 conjured up for the Historical Association of South Africa's (HASA) conference in its sixty-second year of existence, elicited a very broad range of participants and papers. This extended from the wellseasoned to the newly-induced, with topics ranging from the pre-colonial to the second democracy, from tobacco to tattoos, from archives to YouTube, from cannibalism to spiritualism, from floods to droughts, from human rights to corrective rape ... and much more. This reflected on the dynamism and diversity of the discipline as historians continue to endeavour to "untangle the past" 2 in a context where the place and position of the discipline of History has fluctuated in education, in academia and also in popular consciousness.

The title of this article, "History through the looking glass", is taken from the sequel to Lewis Carroll's ${ }^{3}$ Alice's Adventures in Wonderland (1865) entitled Through the Looking Glass, and what Alice Found there which was published in 1871.4 Eighteen-seventy-one was the year when Moeshoeshoe's Basotholand was annexed by the British, when Otto von Bismarck unified Germany, the Japanese Yen was officially adopted, and P.T. Barnum's circus "The Greatest Show on Earth" opened. It was also the year when founder of the Bantu Women's League, Charlotte Maxeke, was born, when Henry Stanley encountered David Livingstone, the anti-Chinese riots broke out in Los Angeles and the world's first cat show took place at the Crystal Palace in London. Random, but relevant to some - all depending on what you - as historian - are looking back at. What is most intriguing about this Alice contextualisation is what literary theorists have subsequently made of what was regarded initially as a fantastical children's novel. ${ }^{5}$

Almost one hundred and fifty years later the interpretations of Alice and the Looking Glass abound. Historical criticism has been used to imbue these two novels with an expansive range of explanations and symbolism. Seen as a political allegory, where Wonderland is a symbolic England and the Queen of Hearts is Victoria, literary analysts claim that this all corresponds with Carroll's own personal disdain of Victorian society, of Queen Victoria herself, of the prevailing legal injustices and of burgeoning colonialism. ${ }^{6}$ On the latter, Alice is interpreted specifically as an allegory about colonisation, when the British Empire controlled huge tracts of land in both

1. $\quad$ http://hgsa.co.za/conference-2018/ Accessed June 2018.

2. $\quad$ http://hgsa.co.za/conference-2018/ Accessed June 2018.

3. Charles Lutwidge Dodgson.

4. L. Carroll, Alice's Adventures in Wonderland (MacMillan \& Co., London, 1865); L. Carroll, Through the Looking Glass, and what Alice Found There (MacMillan \& Co., London, 1871).

5. M. Sandberg, "How Alice in Wonderland Changed Children's Literature", 2 June 2015, at http://blog.connectionsacademy.com/how-alice-in-wonderland-changedchildren-s-literature/ Accessed September 2108.

6. Victorian Interpretations, at https://www.carleton.edu/departments/ENGL/Alice/ CritVict.html Accessed June 2018. 
Africa and India. She is the imperialist and her failure to understand the "native culture" and her insistence on imposing her "own norms and values" eventually leads to her landing in a "life-threatening situation", where the Queen of Hearts calls out: "off with her head!".

Situating the writing of this children's novel - or any event for that matter - in the context of its time, is something historians do almost automatically. It is taken as a given, almost as an indelible non-negotiable. In the fifth edition of John Tosh's In Pursuit of History his opening chapter, after three decades, still forefronts "historical awareness" as key to his introduction to students of history. ${ }^{8}$ Here he refers to historical awareness as something human beings all possess, individually or collectively. He underscores this point by claiming that when someone has lost a sense or consciousness of their personal past, they are regarded as "disqualified from normal life". 9 He continues by saying: "All societies have a collective memory, a storehouse of experience which is drawn on for a sense of identity and a sense of direction".10 This is resonant of the oft quoted Roman politician Cicero who stated: "To be ignorant of what occurred before you were born is to remain always a child".11 This is a sentiment reiterated by Marcus Garvey almost two millenniums later when he maintained: "A people without the knowledge of their past history, origin and culture is like a tree without roots". ${ }^{12}$ As Tosh argues, our identities are informed by our recollections of the past, an awareness of that past is indispensable to who we are, and one might add who we become. However, Tosh cautions that because historians adopt a more "detached approach to the past" they are oftentimes "in conflict with people who feel their cherished versions of the past are under threat". ${ }^{13}$

But reverting back to chapter one of the Looking-glass (the 1526 Victorian word for a mirror ${ }^{14}$ Alice wonders what the world is like on the other side of a mirror's reflection and climbs onto the mantelpiece so that she can see beyond it, only to discover to her surprise that she is able to step through it. The imagery of the mirror reminds us that the reflections are reversed, they are reproductions of the real world but with a difference - they are the "backwards versions" of normal things. ${ }^{15}$ It is here where the title of this article, "History through the looking glass", merges with

7. D. Bivona, "Alice the Child-Imperialist and the Games of Wonderland", NineteenthCentury Literature, 41, 2 (1986) at <http://www.jstor.org/stable/3045136> Accessed June 2018.

8. J. Tosh, In Pursuit of History (Routledge, New York, 2015), p 1.

9. Tosh, In Pursuit of History, pp 1-2.

10. Tosh, In Pursuit of History, pp 1-2.

11. Marcus Tullius Cicero, https://www.goodreads.com/quotes/18978-to-be-ignorantof-what-occurred-before-you-were-born Accessed June 2018.

12. Marcus Garvey, at https://www.brainyquote.com/quotes/marcus garvey 365148If Accessed June 2018.

13. Tosh, In Pursuit of History, p 1.

14. First used in 1526 (Merriman Webster Dictionary).

15. "Alice's Adventures in Wonderland and through the Looking-Glass, at https://www. shmoop.com/alice-in-wonderland-looking-glass/symbolism-imagery.html Accessed June 2018. 
my recollections of Alice: Historians also climb onto their respective mantelpieces to consider a selected element of the past; they reflect back on the bygone or preceding time, but in reverse, because in essence, everything a historian writes about is considered from a backward vantage. In doing so they need to again take heed of the long-standing adage from British novelist L.P Hartley, "The past is another country; they do things differently there", 16 which is often used by historians to caution against the dangers of imposing "modern assumptions on previous ages".17 This historical awareness is summed up by Tosh in three basic principles - an awareness of difference, context and process. ${ }^{18}$ Put simply, a consciousness of the vast difference between now and then; empathy of the context of the setting; and an understanding of the interconnectivity or relationship between events over time. It is therefore imperative that when dealing with this past, whatever the reason or rationale for mounting the mantelpiece to look back into the past, historians need to follow Alice and step through the looking-glass to grasp the array of differences, the specific contexts and the changing processes.

\section{Holding up the Looking Glass}

In 2014, Harvard University professor of History, David Armitage, wrote that for "centuries, even millennia, historians [have] advised rulers, enlightened citizens and shaped policy".19 In his article entitled "Why Politicians Need Historians", he calls upon policymakers to take "lessons from the past" and employ historians, pointing out that "one benefit of historical perspective is learning that it wasn't always that way" and claiming that the historian's longue durée - the longer reflection - will inform better policy that is enduring as opposed to being temporary or contingent. ${ }^{20}$ In her presidential address at the South African Historical Society conference in 2015 (and later published in the South African Historical Journal of 2016), ${ }^{21}$ Sandra Swart makes a similar point on how for centuries "historians counselled rulers" and argues that because historians are "trained to understand nuance, uncover complexity and eschew partisanship" they need to "insert [them]selves into ... public debates" and "comment publically".22 Armitage argues that historians need to "overcome their fastidiousness" and step up to "shape public policy".23

In the light of these well-seasoned views, it is incumbent on the historical fraternity, and historians themselves, to mount the mantelpiece and look through the

16. L.P. Hartley, The Go-Between (Penguin, London, 1958), p 7.

17. Tosh, In Pursuit of History, p 10.

18. Tosh, In Pursuit of History, pp 9-12.

19. D. Armitage, "Why Politicians Need Historians", The Guardian, 7 October 2014, at https://www.theguardian.com/education/2014/oct/07/why-politicians-needhistorians Accessed September 2018.

20. Armitage, "Why Politicians need Historians", The Guardian, 7 October 2014.

21. S. Swart, “'Dangerous People' or How I Learned to Stop Worrying and Love being an Historian", South African Historical Journal, 68, 3 (2016), pp 252, 255.

22. Swart, "Dangerous People", p 255.

23. Armitage, "Why Politicians need Historians", The Guardian, 7 October 2014. 
looking glass to reflect on the recent pronouncement by one of the country's leaders. I refer here to the Minister of Basic Education, Angie Motshekga, on the topic of introducing history as a compulsory subject at school in grades 10, 11 and 12 from $2023 .{ }^{24}$ It is a matter raised by Swart in this context, ${ }^{25}$ but one of such importance that it warrants more reflection given the concomitant groundswell of reaction to the announcement on social media and in the tabloids. ${ }^{26}$

It appears that this issue was raised initially by the South African Democratic Teachers' Union (SADTU) when they met with the Minister of Education in June of 2014. SADTU believed that history should be made compulsory at high schools and declared it wanted "history textbooks to be rewritten to tell 'the real' South African story". ${ }^{27}$ The deputy general secretary of SADTU, Nkosana Dolopi, claimed the youth "have to understand the past to build a stronger future", pointing out that history is "prioritised in most developing countries such as Cuba". ${ }^{28}$ In the face of some opposition, including ongoing politically loaded accusations of "ideological brainwashing" and "curriculum overkill",29 SADTU requested that "extensive research" should be conducted on the proposal. ${ }^{30}$

This formal process began in 2015 when a seven-member Ministerial Task Team (MTT), including historians and other academics, was appointed by the minister under the leadership of Professor Sifiso Ndlovu, with the following mandate:

- advise on the feasibility of making History compulsory;

- where History should be located in the curriculum (for example, whether it should be incorporated into Life Orientation or not);

- review the content and pedagogy of the History curriculum with a view to strengthening History in the curriculum;

24. R. Pather, "Education Task Team: History Should be a Compulsory School Subject from 2023", Mail \& Guardian, 31 May 2018, at https://mg.co.za/author/raeesa-pather Accessed June 2018.

25. Swart, "Dangerous People", p 264.

26. T. Kubheka, "Proposal to Make History Compulsory not an Attempt to Politicise Classroom”, 31 May 2018, https://ewn.co.za/2018/05/31/proposal-to-makehistory-compulsory-not-an-attempt-to-politicise-classroom Accessed June 2018; P. Mulder, "Geskiedenis 'n Verpligte Vak tot Matriek?", at https://maroelamedia.co.za/author/ pietermulder Accessed June 2018; A. Umraw, "Compulsory History Classes: Who Decides What We Learn and What We Forget?", at https://www.huffingtonpost. co.za/2018/05/31/compulsory-history-classes-whodecides-what-we-learn-and-what-we-forget a 23447798/ Accessed June 2018.

27. P. Louw and N. Davids, "Rewrite SA Story - Union", The Times, 23 June 2014, p 1.

28. Louw and Davids, "Rewrite SA Story - Union”, The Times, 23 June 2014, p 1.

29. L. Jansen "Hitch in Bid to Make History Compulsory", Pretoria News, 13 October 2015, p 2.

30. R. Molefe, "Sadtu backs Motshekga in Compulsory History Call", The New Age, 18 July 2014, p 2. 
- investigate the implications (for teaching, classrooms, textbooks, etc.) of making History a compulsory subject. ${ }^{31}$

The activities of the MTT involved a comparative study with a dozen countries in Africa, the East and West including Russia, Zimbabwe, Rwanda, Nigeria, India, Poland, Netherlands, Italy, France, Brazil, Austria and China; ${ }^{32}$ country-wide provincial consultations; a detailed review of the prevailing CAPS system (Curriculum and Assessment Policy Statement); as well as an appraisal of the training of history teachers at universities throughout the country. ${ }^{33}$ The rationale for the selected countries was not provided although they do represent a sprinkling of the global north and global south, developing and developed countries, with a very wide array of political, social and economic dispensations. Cuba was not included. The provincial consultations were random to say the least, while the appraisal of the training proved to be the reiteration of a similar exercise conducted simultaneously by the Council of Higher Education. ${ }^{34}$ That CAPS was reappraised was reflective of a perpetuated rhythm pertaining to History syllabi and methodologies dating back to the previous century.

That there was much deliberation and possibly even dissidence throughout this Ministerial Task Team process, is as apparent as it is welcomed. At one point in the report it is stated that "the time is ripe for a completely restructured and overhauled curriculum",35 but ten pages on, it states that the team is "against the exercise of wholesale changes or a complete overhaul of the CAPS syllabus and content at this present time", and indicates that this would be "too soon". ${ }^{36}$ Rather, the report advocates a focus on using the CAPS syllabus as the "basis of strengthening the content in the interim" in the hope that the Department of Basic Education will, in future "look to this". Detailed suggestions for this "strengthening" are however presented in the report for grade 4 through to grade 12 . This all appears as if the MTT entered the room, just like Alice, drank from the "Drink-me" bottle and shrank, eventually dashing down yet another rabbit-hole.

However, most significantly and critically for the discipline as a whole, is the concern about "teacher development" which the report addresses directly, along with the all-important point made that the status of History should be restored within the Department of Basic Education - as is the case with Science, Mathematics and Technology. ${ }^{37}$ The penultimate section of the report presents four possible scenarios of how History should be implemented: a compulsory fifth fundamental; as a

31. Report of the History Ministerial Task Team (hereafter MTT) for the Department of Basic Education, February 2018, p 8.

32. Report of the History MTT, February 2018.

33. Report of the History MTT, February 2018.

34. Council on Higher Education, "History Departments at South African Universities", Briefly Speaking, 4 January 2018, pp 1-33.

35. Report of the History MTT, February 2018, p 73.

36. Report of the History MTT, February 2018, p 84.

37. Report of the History MTT, February 2018, p 114. 
replacement for Life Orientation from Grade 9; be integrated into Life Orientation; or completely replace Life Orientation. ${ }^{38}$

Finally, the report concludes with a set of recommendations to the Minister of Education. Here the MTT states unequivocally that History should be made compulsory and that it should be a stand-alone subject. It then indicates that should the Department of Basic Education decide to make History compulsory, there is a range of factors and many concerns that need to be addressed such as "capacity, teacher training, content, textbook alignment, planning as well as budgetary and cost implications". ${ }^{39}$ There is also reference to universities being involved in the process and the importance of Africa-centeredness when revisiting content. Given the range of considerations a "phased approach" is recommended - and hence the setting of a 2023 target. It is therefore a given that History will be compulsory in secondary education and that this will have profound implications for tertiary institutions.

One could argue that this should be an occasion for unrestrained celebration, a true "wonderland" for all those involved in the teaching of the discipline of History because it guarantees a future for the study of the past. But as the Cheshire Cat would have us believe - "things are not always as they seem". The reaction to Minister Motshekga's announcement on 31 May 2018 was mixed. On the one hand there was the expected party partisan approval, while on the other, there was a positive but deeply cautious reception, hinging on acceptance in principle but definitely not in practice.

Linda Chisholm and Michelle Friedman, both academics steeped in history in education as well as history of education, contributed to an article entitled "South Africa Wants to Make History Compulsory at School but is it Doable?". Their comments indicate that the proposal "faces steep challenges" the most important being the "availability of enough well-trained history teachers to meet the demand". And although the report acknowledges this, Chisholm and Friedman argue that it "underestimates what will be needed to train new teachers". ${ }^{40}$ They claim that:

The ability to prepare new history teachers to meet the demand for a policy like this will be hamstrung by two things: the low status of history and teacher education in general in universities; and ongoing budget cuts. ${ }^{41}$

Moreover, they point out that:

38. Report of the History MTT, February 2018, pp 123-129.

39. Report of the History MTT, February 2018, pp 130-134.

40. L. Chisholm and M. Friedman, "South Africa Wants to Make History Compulsory at School but is it Doable?", Huffpost, https://www.huffingtonpost.co.za/staff-reporter/ south-africa-wants-to-make-history-compulsory-at-school-but-can-it a 23450247/ Accessed June 2018.

41. Chisholm and Friedman, "South Africa Wants to Make History Compulsory at School". 
... education faculties have one of the most important jobs at universities - to prepare teachers properly to ensure that the entrants from schools to other faculties are well-qualified. Yet they are at the bottom [the very bottom] of the food chain when it comes to funding and resources. ${ }^{42}$

Other reaction focused on the Africanisation of the curriculum and the importance of teaching history from an African perspective; ${ }^{43}$ the challenges facing the selection of content for a new curriculum; ${ }^{44}$ the concern that ANC myths could just replace Afrikaner myths; ${ }^{45}$ and whether learners were "capable of dealing with educational, social and political problems if they view these problems as ahistorical". 46

There was also a reaction on social media and political platforms which was predominantly derogatory with tweets that history was a "useless subject"; that it could be studied in your "spare time"; that students should focus on STEM (Science, Technology, Engineering and Maths) if they wanted to escape poverty; and the government should "stop playing games with these kids futures". ${ }^{47}$ A member of the Executive Council in the Western Cape also added her two cents worth stating that "We don't need a nation of historians - we need a nation of mathematicians, scientists, artisans, accountants and computer coders". ${ }^{48}$ As an aside, the Honourable MEC would do well to read a recent study completed by the Royal Bank of Canada concerning the skills that the Canadian job market will require between 2018 and 2021. An assessment of " 20000 skills ranking across 300 occupations and 2.4 million expected job openings, shows an increasing demand for foundational skills" such as critical thinking, reading comprehension, active listening and speaking, while the "least important skills include science programming and technology design". 49 In other words, "soft skills" will be most needed for human work. ${ }^{50}$ Be that as it may, the ministerial project will need to take heed of these negative sentiments reflected in popular consciousness and address them as part of its new positioning of History if this is not going to be the eventual demise of the subject.

42. Chisholm and Friedman, "South Africa Wants to Make History Compulsory at School".

43. B. Parker, "In 5 Years, Life Orientation will no Longer be Compulsory, but History will be", Parent24, available at https://m.parent24.com/Learn/High-school/in-5-yearslife-orientation-will-no-longer-be-compulsory-but-history-will-be-20180601 Accessed June 2018.

44. Umraw, "Compulsory History Classes: Who Decides What We Learn and What We Forget?"

45. Mulder, "Geskiedenis 'n Verpligte Vak tot Matriek?"

46. N. Robinson, "[Opinion] The Way History is Taught in SA is Ahistorical: And that's a Problem", Eyewitness News, http://ewn.co.za/2018/06/08/opinion-the-way-historyis-taught-in-sa-is-ahistorical-and-that-s-a-problem Accessed June 2018.

47. Siphamandla (@Sowellnomics) 31 May 2018; Vusi Sambo (@VusiSambo) 31 May 2018.

48. F. Villette, “We Don't Need a Nation of Historians”, Cape Times, 18 June 2018.

49. T. Bates, "Humans Wanted: Online Learning and Skills Development", 10 April 2018, at https://www.tonybates.ca/2018/04/10/humans-wanted-online-learning-andskills-development/Accessed June 2018.

50. Bates, "Humans Wanted: Online Learning and Skills Development". 


\section{Reflecting in the Looking Glass}

Taking the longer view and looking back in the reverse, this is not the first time that history and the education curriculum have been revisited and commented upon. Nor is this an exercise germane to South Africa. Since the late twentieth century, the place of history and its curriculum at both school and university have been the subject of reports, scrutiny and debate in the United Kingdom, United States, New Zealand, Australia and Africa. ${ }^{51}$ Furthermore, it is not the first time that there has been a change in the profile and place of history in the broader educational domain in South Africa. ${ }^{52}$ In point of fact, since the establishment of the new democratic dispensation in 1994 history has metamorphosed and at stages almost become extinct through the various attempts at rectifying the education system. These include, but are probably not limited to the half dozen mutations in the span of two decades: the Interim Core syllabus (1996), Outcome Based Education (1997), Curriculum 2005 (1997/98), Revised National Curriculum Statement (2002), the New National Curriculum Statement (2003) and the Curriculum and Assessment Policy Statement (2009/2011).

Reflecting on history and the post-apartheid period, Rob Siebörger recalls the sense of "great expectancy in the years between the release of Nelson Mandela in 1990 and the first democratic election in South Africa in 1994". ${ }^{33} \mathrm{He}$ heralds this as a time when:

History teachers, history educationalists and historians looked forward with impatient anticipation to the time when the apartheid curriculum would be cast aside and history could claim its place as an important instrument in the construction of the new national identity. ${ }^{54}$

He admits that the task that lay ahead was a daunting one, but feels that it was not unrealistic. He pointed hopefully to the fact that the country had a national curriculum, albeit it an Afrikaner nationalist one, but felt there was a core syllabus to work with in terms of changing the curriculum format. He was also optimistic about the "vigorous scholarship of historians many of whom worked outside the country" producing alternative texts and espoused a skills-based discipline-led pedagogy. ${ }^{55}$

51. G. Cuthbertson and A. Grundlingh. "Some Problematic Issues in Restructuring of History Education in South African Schools", South African Historical Journal, 26 (1992), pp 155-156.

52. See for example T.F. Ebot, "The History of History Writing in South African Secondary Schools, 1994-2006", MA mini-thesis, University of the Western Cape, 2008.

53. R. Siebörger, "History and the Emerging Nation: The South African Experience", School of Education, University of Cape Town, n.d., p 1.

54. Siebörger, "History and the Emerging Nation", p 1.

55. Siebörger, "History and the Emerging Nation", p 1. 
In 1990 Melanie Walker reflected on the "grossly unequal education" in South Africa which was "firmly rooted in the barren soil of Bantu Education". ${ }^{6}$ Not only had the financial allocation for education been disproportionate, but the racial division was perpetuated by a segregated system. ${ }^{57}$ Yet despite this divided structure, which at one point had no less than 15 education authorities, (others claim there were 18) she also described education as being a "highly centralised affair" with the white parliament in control. 58 The controlled syllabus, which reflected apartheid ideology, also determined the content of history teaching, while the language of the textbooks also underscored apartheid ideology. ${ }^{59}$ She called for teachers to start democratising the educational process by changing both the "methods and content of history teaching" in order to bring about "broad structural change" and "produce pupils and students who [would] be able themselves to participate in the struggle for full freedom for all in [the] country. ${ }^{60}$

Another of the leading scholars in history education at the time, Peter Kallaway, was more pensive about the place of history on the cusp of the new dispensation. In an article on history education in the new democracy he begins by posing a dozen or so questions and asks rhetorically whether "a controversial and potentially divisive subject like history [should] be taught in the schools of the new South Africa?"61 Furthermore he questioned: "What historiography will we tap into for a satisfactory curriculum that redresses past imbalance but leaves space for the history of all the people?"62 A final query was, "In short, how do we define the necessary conditions for a satisfactory school history in the new democratic context?"63 At this time Kallaway exclaimed that given the "magnitude of the task and the multiple challenges to be confronted" one tended to loose heart. ${ }^{64}$ He concluded his article by admitting that although the challenges for the formulation of history education policy were considerable, there was also a "considerable legacy of alternative history in schools" which placed it in a stronger position to meet the challenges of the future. 65

The combined optimism, pessimism and scepticism apparent in the writings of these three leading education scholars on the question of the place and position of history in the new democracy was uncannily predictive of what was destined to unfold over the next three decades. This situation, I believe, remains just as apparent

56. M. Walker, "History and History Teaching in Apartheid South Africa", Radical History Review, 46, 7 (1990), p 299.

57. S. Badat, "Black Student Politics, Higher Education and Apartheid: From SASO to SANSCO, 1968-1990” (HSRC Press, Pretoria, 1999), p 50.

58. Walker, "History and History Teaching in Apartheid South Africa", p 299.

59. Walker, "History and History Teaching in Apartheid South Africa", pp 303-304.

60. Walker, "History and History Teaching in Apartheid South Africa", p 306.

61. P. Kallaway, "History Education in a Democratic South Africa", Teaching History, 78, (January 1995), p 11.

62. Kallaway, "History Education in a Democratic South Africa”, p 11.

63. Kallaway, "History Education in a Democratic South Africa", p 11.

64. Kallaway, "History Education in a Democratic South Africa", p 11.

65. Kallaway, "History Education in a Democratic South Africa”, p 16. 
in a closer reading of the 2018 Report of the History Ministerial Task Team where positivity, apprehension and doubt still pervade.

The first attempt at addressing the educational crisis and in particular History within the educational system reflected very much the compensational stance of the Government of National Unity (GNU). ${ }^{66}$ Education academic Jonathan Jansen has referred to this as "compensatory legitimation" or "political symbolism",67 while history education scholar Paul Maluleka suggests that any change made by the new GNU was done in a symbolic way to prove to South Africa, and the world, that the African majority could govern. ${ }^{68}$ In line with this, in 1994, the new Minister of Education, Sibusiso Bengu, embarked on an interim revision of school syllabuses with the mandate to remove "inaccuracies, outdated and contentious content", ${ }^{69}$ but with the proviso that this was to be done without necessitating new textbooks. ${ }^{70}$ The "bargaining forum" set up for this purpose, the National Education and Training Forum (NETF), maintained the combination of History and Geography as a sub-field of Social and Human Sciences which had been initially devised by the Educational Renewal Strategy of the early 1990s. According to Cynthia Kros, history education academic, the Interim Core Syllabus for History was "devised in the unhealthy and exclusive atmosphere of 'secretive quid pro quo brokerage"'71 with Siebörger declaring that those involved were "subject to criticism" and the result "pleased few if anyone". ${ }^{72}$ Like the Cheshire Cat, history as a stand-alone discipline, was beginning to disappear.

Three years into democracy and the government launched Outcomes Based Education (OBE) which was set to inform the new school curriculums along with the National Qualifications Framework (NQF). This was essentially a shift away from content-based teaching whereby subjects were integrated into learning areas so as to combine education and training, partly as a response to pressure from labour movements. ${ }^{73}$ It was then that History was merged into a conglomerate with Geography as a Human and Social Science learning area and thus essentially vanished from the curriculum. ${ }^{74}$ According to Siebörger, it was "possible to teach the

66. P. Maluleka, "To Understand SA's History Curriculum Change in Democracy, Lets First look at this Change during Transformation", news24.com, 15 January 2015.

67. J. Jansen, "The School Curriculum since Apartheid: Intersections of Politics and Policy in the South African Transition", Unpublished Paper, University of Pretoria, 1999.

68. Maluleka, "To Understand SA's History Curriculum Change in Democracy, Lets First Look at this Change during Transformation".

69. Siebörger, "History and the Emerging Nation", p 2.

70. Siebörger, "History and the Emerging Nation", p 2.

71. C. Kros, "Trusting to the Process: Reflections on the Flaws in the Negotiating of the History Curriculum in South Africa, Report 1", University of the Witwatersrand, Johannesburg, 1996.

72. Siebörger, "History and the Emerging Nation", p 2.

73. C. Bertram, "Knowledge, Pedagogy and Assessment in the Old and the New Further Education and Training History Curriculum Documents", Education as Change, (December 2006), p 35; Siebörger, "History and the Emerging Nation", p 2.

74. Siebörger, "History and the Emerging Nation", p 2. 
curriculum faithfully with some reference to the past but never actually [teaching] history - it was for all intent and purposes essentially eliminated as a discrete subject in the new Curriculum 2005".75 In a manner of speaking it was now a "grin without a cat", evoking Alice's thoughts that it was "the most curious thing [she] ever saw in [her] life!"

Linda Chisholm critiqued Curriculum 2005 on the very foundations on which it was built - it had no specified content and had integrated distinct subjects into learning areas. ${ }^{76}$ Citing Taylor, Kallaway deferred to this as the "most radical constructivist curriculum ever attempted anywhere in the world", one which integrated different disciplines creating a "pot pourri of curriculum proposals with largely unacknowledged origins". ${ }^{77}$ Education historian Y. Seleti also criticised this as the "end of History" commenting that it was not "educationally, intellectually or politically correct" to do away with specialisation in the higher grades. ${ }^{78}$ More vociferous was Jonathan Jansen's ten-point diatribe on why OBE would not work within a South African educational context, laying the blame for this on an incompetent Education Ministry bent on putting "something innovative into the schools at all costs in order to reclaim political credibility".79 Like Alice, it appeared that the education system had to "go backwards to go forwards".

In 2001, it was the new Education Minister, Kader Asmal, who was critical in moving the situation forward. In a speech he indicated that:

Conflating history with geography in a generalized field of human social sciences [had] compromised its unique disciplinary virtues and seriously eroded its status. ${ }^{80}$

He was also responsible for instigating a Review of Curriculum 2005 under the leadership of Chisholm as well as the "History and Archaeology Panel of the Values in Education Initiative". The panel endorsed the Review's recommendation that History

75. R. Siebörger, "A Reply to Peter Kallaway, 'History in High School 2012: A Comment on Curriculum and Assessment Policy Statement, History Grades 10-12'”, School of Education, University of Cape Town Seminar, 9 May 2018; Bertram, "Knowledge, Pedagogy and Assessment in the Old and the New Further Education and Training History Curriculum Documents", p 35.

76. Bertram, "Knowledge, Pedagogy and Assessment in the Old and the New Further Education and Training History Curriculum Documents", p 35.

77. P. Kallaway, "History in Senior Secondary School, CAPS 2012 and Beyond: Comment", Yesterday and Today, 7 (July 2012), pp 23-24.

78. Y. Seleti, "From History to Human Social Sciences", Education Policy Unit Working Paper, No. 14, 1997, cited in Bertram, "Knowledge, Pedagogy and Assessment in the Old and the New Further Education and Training History Curriculum Documents", p 35.

79. J. Jansen, "Curriculum Reform in South Africa: A Critical Analysis of Outcomes-Based Education", Cambridge Journal of Education, 28, 3 (1998), pp 321-331.

80. Bertram, "Knowledge, Pedagogy and Assessment in the Old and the New Further Education and Training History Curriculum Documents", p 36, footnote 1. 
and Geography be "addressed separately in the Social Sciences Learning Area" and so once again History became "separate and distinct".81 The ministerial "SA Schools History Project" ensued and was among others involved in developing the new Revised National Curriculum Statement for Social Sciences (RNCS) in 2002 and the National Curriculum Statement (NCS) for History in 2002.82 An analysis by Carol Bertram indicates that the NCS presents knowledge in a more integrated fashion with a greater focus on the learner while emphasising the development of "historical skills of enquiry" and "cognitive skills of understanding and analysis". Under Asmal's ministry, a National History Commission was also established and mandated to strengthen the "teaching of history in schools". ${ }^{3}$ History, just like Alice and the Cheshire Cat: " ... where it had been, it suddenly appeared again".

By 2009 the Minister of Basic Education, Angie Motshekga, indicated that there were "ongoing implementation challenges" with RNCS and she instigated a review. The new Curriculum and Assessment Policy Statement (CAPS), which emerged in 2011, proclaimed to provide "clearer specification of what is to be taught and learnt on a term-by-term basis"; it combined the former two 2002 curricula into one and provided policies pertaining to promotion as well as assessments. ${ }^{84}$ This amounted to a limited revision and streamlining of the NCS in "order to make it clearer... and to fill content gaps where they [existed]". 85 The minster indicated that it was the "culmination of our efforts over a period of seventeen years to transform the curriculum bequeathed to us by apartheid". While many, including Kallaway, have recognised its value, it too has been critiqued for its viability.86 In 2012 Siebörger commented that all his years of experience of history curriculum committees had taught him "one inescapable truth", namely that "it will never be possible to create the ideal history content, nor to satisfy all members of the committee, let alone the academic and teaching professions or general public". ${ }^{87}$

What the Ministry of Basic Education has done over the past almost quarter of a century is to stay true to Oscar Wilde's quip, that "the one duty we owe to history is to rewrite it", and so they have. The powers that be have rewritten the history curriculum and its place within the education system. And in Wonderland idiom, history, like the Cheshire Cat, is back again after vanishing. There are indeed conflicted concerns about its position and practice - yet like the fantastical tale, we as

81. Bertram, "Knowledge, Pedagogy and Assessment in the Old and the New Further Education and Training History Curriculum Documents", p 36.

82. Siebörger, "A Reply to Peter Kallaway: 'History in High School 2012'”.

83. Bertram, "Knowledge, Pedagogy and Assessment in the Old and the New Further Education and Training History Curriculum Documents", p 36.

84. Department Basic Education, National Curriculum Statement, Curriculum Assessment Policy, Pretoria, 2011, p i.

85. Siebörger, "A Reply to Peter Kallaway: 'History in High School 2012'”.

86. Kallaway, "History in Senior Secondary School CAPS 2012 and Beyond: Comment", p 23.

87. Siebörger, “A Reply to Peter Kallaway: 'History in High School 2012'”. 
historians must remain "curiouser and curiouser" as we continue to peer expectantly into the past to see History through the Looking Glass.

\section{REFERENCES}

"Alice's Adventures in Wonderland; and through the Looking-glass", available at https://www.shmoop.com/alice-in-wonderland-looking-glass/symbolismimagery.html Accessed April 2018.

Armitage, D., "Why Politicians need Historians", The Guardian, 7 October 2014, at https://www.theguardian.com/education/2014/oct/07/why-politicians-needhistorians Accessed September 2018.

Badat, S., Black Student Politics, Higher Education and Apartheid: From SASO to SANSCO, 1968-1990 (HSRC Press, Pretoria, 1999).

Bates, T., "Humans Wanted: Online Learning and Skills Development", 10 April 2018, https://www.tonybates.ca/2018/04/10/humans-wanted-online-learning-andskills-development/ Accessed June 2018.

Bertram, C., "Knowledge, Pedagogy and Assessment in the Old and the New Further Education and Training History Curriculum Documents", Education as Change, (December 2006).

Bivona, D., "Alice the Child-Imperialist and the Games of Wonderland", NineteenthCentury Literature, 41, 2 (1986), available at http://www.jstor.org/stable/ $\underline{3045136}$ Accessed May 2018.

Carroll, L., Alice's Adventures in Wonderland (MacMillan \& Co., London, 1865).

Carroll, L., Through the Looking Glass, and What Alice Found There (MacMillan \& Co., London, 1871).

Chisholm, L. and Friedman, M., "South Africa Wants to Make History Compulsory at School but is it Doable?", Huffpost, https://www.huffingtonpost.co.za/staffreporter/south-africa-wants-to-make-history-compulsory-at-school-but-canit a $23450247 /$ Accessed June 2018

Council on Higher Education, "History Departments at South African Universities", Briefly Speaking, 4 January 2018.

Cuthbertson, G. and Grundlingh, A., "Some Problematical Issues in the Restructuring of History Education in South African Schools", South African Historical Journal, 26, (1992).

Department of Basic Education, "National Curriculum Statement, Curriculum Assessment Policy", Pretoria, 2011.

Ebot, T.F., "The History of History Writing in South African Secondary Schools, 19942006", MA mini-thesis, University of the Western Cape, 2008.

Hartley, L.P., The Go-Between (Penguin, London, 1958).

Historical Association of South Africa, http://hgsa.co.za/conference-2018/ Accessed June 2018.

Jansen, J., "Curriculum Reform in South Africa: A Critical Analysis of Outcomes-Based Education”, Cambridge Journal of Education, 28, 3 (1998). 
Jansen, J., "The School Curriculum since Apartheid: Intersections of Politics and Policy in the South African Transition", Unpublished paper, University of Pretoria, 1999.

Jansen, L., "Hitch in Bid to Make History Compulsory", Pretoria News, 13 October 2015.

Kallaway, P., "History Education in a Democratic South Africa", Teaching History, 78 (January 1995).

Kallaway, P., "History in Senior Secondary School CAPS 2012 and Beyond: Comment", Yesterday and Today, 7 (July 2012).

Kros, C., "Trusting to the Process: Reflections on the Flaws in the Negotiating of the History Curriculum in South Africa, Report 1", University of Witwatersrand, Johannesburg, 1996.

Kubheka, T., "Proposal to Make History Compulsory not an Attempt to Politicise Classroom", 31 May 2018, https://ewn.co.za/2018/05/31/proposal-to-makehistory-compulsory-not-an-attempt-to-politicise-classroom Accessed June 2018.

Louw, P. and Davids, N., “Rewrite SA Story - Union”, The Times, 23 June 2014.

Maluleka, P., "To Understand SA's History Curriculum Change in Democracy, Let's First Look at this Change during Transformation", news24.com, 15 January 2015.

Marcus Garvey, at https://www.brainyquote.com/quotes/marcus garvey 365148If Accessed June 2018.

Marcus Tullius Cicero, https://www.goodreads.com/quotes/18978-to-be-ignorantof-what-occurred-before-you-were-born Accessed June 2018.

Molefe, R., "Sadtu Backs Motshekga in Compulsory History Call", The New Age, 18 July 2014.

Mulder, P., "Geskiedenis ' $\mathrm{n}$ verpligte vak tot matriek?", available at https://maroelamedia.co.za/author/pietermulder Accessed June 2018.

Parker, B., "In 5 Years, Life Orientation will no Longer be Compulsory, but History will be", Parent24, available at https://m.parent24.com/Learn/High-school/in-5years-life-orientation-will-no-longer-be-compulsory-but-history-will-be20180601 Accessed June 2018.

Pather, R., "Education Task Team: History should be a Compulsory School Subject from 2023", Mail \& Guardian, 31 May 2018, at https://mg.co.za/author/raeesapather Accessed June 2018

Robinson, N., “[Opinion] The Way History is Taught in SA is Ahistorical - and That's a Problem", Eyewitness News at http://ewn.co.za/2018/06/08/opinion-the-wayhistory-is-taught-in-sa-is-ahistorical-and-that-s-a-problem Accessed June 2018.

Seleti, Y., "From History to Human Social Sciences", Education Policy Unit Working Paper, No. 14, 1997, as quoted by C. Bertram, "Knowledge, Pedagogy and Assessment in the Old and the New Further Education and Training History Curriculum Documents", Education as Change (December 2006). 
Siebörger, R., "A Reply to Peter Kallaway's 'History in High School 2012: A Comment on Curriculum and Assessment Policy Statement. History Grades 10-12'”, School of Education, University of Cape Town Seminar, 9 May 2012.

Siebörger, R., "History and the Emerging Nation: The South African Experience", School of Education, University of Cape Town, n.d.

Sambo, V., (@VusiSambo) 31 May 2018.

Sandberg, M., "How Alice in Wonderland Changed Children's Literature”, 2 June, 2015, at http://blog.connectionsacademy.com/how-alice-in-wonderland-changedchildren-s-literature/ Accessed September 2108.

Siphamandla (@Sowellnomics), 31 May 2018.

Swart, S., “'Dangerous People', or How I Learned to Stop Worrying and Love being an Historian"', South African Historical Journal, 68, 3 (2016).

Tosh, J., In Pursuit of History (Routledge, New York, 2015).

Umraw, A., "Compulsory History Classes: Who Decides What we Learn and What we Forget", at https://www.huffingtonpost.co.za/2018/05/31/compulsoryhistory-classes-who-decides-what-we-learn-and-what-we-forget a 23447798/ Accessed June 2018.

Victorian Interpretations, at https://www.carleton.edu/departments/ENGL/Alice/ CritVict.html Accessed April 2018.

Villette, F., “We Don't Need a Nation of Historians”, Cape Times, 18 June 2018.

Walker, M., "History and History Teaching in Apartheid South Africa", Radical History Review, 46, 7 (1990). 